\title{
STEM Library Activities in Croatian Primary School Curriculums
}

\author{
Ana Rendulič \\ Josip Kozarac Primary School \\ anarenduli6@gmail.com
}

Keywords: STEM, Curriculum, School Librarians, School Libraries

\begin{abstract}
The goal of this paper is to give an overall picture of STEM activities in school curriculums supported by school librarians in primary schools in Croatia. Qualitative content analysis was the research methodology used to examine Croatian primary school curriculums, which are the main planning documents for all school activities. There are 904 primary schools in Croatia, according to the official list provided by the Ministry of Science and Education in Croatia (Ministarstvo znanosti i obrazovanja Republike Hrvatske, 2019). The research examined the curriculum documents available on the official web pages of 854 Croatian primary schools. The research findings, based on school year 2018/2019, give a general picture of STEM activities in school curriculum, involving librarians, in six categories: science, green libraries, technology, engineering, mathematics, and extracurricular activities.
\end{abstract}

\section{Introduction and Research Purpose}

STEM education is a global trend in schools and other educational institutions. The STEM acronym originates from the acronym SMET used in 1990s by National Science Foundation (NSF); it was an abbreviation for science, mathematics, engineering, and technology. Due to phonetic and semantics reasons, SMET became STEM: science, technology, engineering and mathematics (Sanders, 2009). Today STEM it is an acronym known worldwide in the educational context. Sanders (2009) thinks it is not possible for one teacher to effectively cover all the aspects of STEM knowledge. He emphasizes the importance of expertise in STEM fields, and he is sceptical of the idea that STEM contributes something new and exciting to education. Therefore, he states that experts from various fields need "integrative ideas, approaches, instructional materials, and a curriculum" (Sanders, 2009, p. 22).

In order to perform STEM activities well, curricular planning is necessary. "The potential gains and influence of quality STEM curriculum and instruction at the elementary level provide justification for supporting efforts to increase elementary teachers' capacity to teach STEM" (Nadelson, 2013, p. 158). Glatthorn et al. (2019) asserts the strong relationship between technology and curriculum: "Any written curricula must be adapted to emerging technologies." The STEM curriculum should transform learning environments by giving students access to technology and by transforming teaching practices. Many of the essential general curriculum skills are also skills that STEM education is based on: problem solving, creativity, analytical thinking, cooperation and communication (Glatthorn et al., 2019, p. 19). STEM implies an interdisciplinary approach to learning, problem solving and project teaching. 
The school curriculums in Croatia are considered to be the main documents for planning and executing not only core school subjects and activities; they also include a subsection on elective courses and rehabilitation programs, and another subsection in which are listed all the extracurricular activities, school projects, out-of-classroom teaching, school programs, and cultural public activities (Nacionalni okvirni kurikulum, 2017). Through the content analysis of school curriculum documents, we are able to find out about planned library programs including representations and quality of STEM activities. As a concept, STEM is becoming increasingly relevant not only in education overall, but in educational and entertaining library activities as well. Mardis (2007) notes that "it is increasingly important for every component of the learning environment to have demonstrable effect and to be mutually reinforcing."

As professional associates, librarians play an important role in student learning. The educational work of school librarians in Croatia is traditionally related to the school subject Croatian language and to extracurricular activities related to that subject and to books and reading. However, librarians also should be aware of their influence in other educational areas, as indicated in global frameworks and in guidelines and trends in librarianship and education overall. There are numerous works that emphasize the role of the library in facilitating STEM education (Mardis, 2007, Subramaniam et al., 2013, Pards, 2018, Subramaniam et al., 2013, Johnston, 2017). Johnston (2017) states that teacher librarians could provide "real-world collaborative learning opportunities to promote STEM learning."

The extent to which Croatian school librarians plan STEM activities and address related topics has not previously been investigated. The goal of this study is to describe STEM activities presented in school curriculums by librarians as activity managers, in order to get a deeper understanding of curricular planning for STEM activities occurs and how STEM is integrated into school curriculums.

\section{Literature Review}

There are a few studies that examine the role of the school librarian in conducting of STEM activities. All of them emphasize positive effects of librarians' engagement in conducting of STEM activities in schools. However, according to those studies, majority of school librarians do not accept STEM education as their field of activity. School librarians are encouraged by library associations to involve themselves into STEM concept that seems to be becoming an increasingly important issue and global trend, judging by national and global initiatives to support fresh and exciting STEM education in schools. This is also evident in the award winning research paper of the 2017 IASL Conference: "Preparing Teacher Librarians to Support STEM Education" by Melissa P. Johnston. Johnston conducted a needs assessment among school librarians in rural areas of the south-eastern U.S. with a goal of finding out "what are the knowledge, skills, and abilities of teacher librarians in order to support STEM learning” (Johnston, 2017, p. 4). Using key informant interviews and observations, she was able to identify specific needs which librarians should address in order to successfully carry out STEM activities.

Numerous studies have addressed barriers to connecting school libraries and STEM education. School librarians differ in their academic and professional backgrounds, as well as their interests (Subramanian, 2013, p. 11). A common barrier is librarians' lack of knowledge in science, since many come from humanities and social science backgrounds. Science teachers often do not recognize librarians as their colleagues and usually rely upon themselves, textbooks, internal materials and materials on the web. Librarians themselves rarely address topics related to STEM due to lack of confidence and subject knowledge or expertise (Mardis, 2007; Crystle, 2017). Crystle (2017) stated that successful librarians are the ones who are flexible, who are willing to try something new, fail, make changes on the go and be ok with the idea of not being the expert.

International Association of School Librarianship

https://iasl-online.org 
Mardis (2007) describes a research study which examined the relationship between school library media programs and science achievement in eight-grade students from Michigan. The findings suggested that video in the school library collection has the strongest relationship with science achievement and that library media specialists' confidence in engaging science teachers is linked to their personal confidence and experience with science topics. However, poverty-related factors overwhelmed all the school library media variables in their relationship to science achievement. Niemi et al (2014) promotes digital storytelling (DST), where students' videos are used as motivational tools for learning. Many authors recognize technology as a catalyst for better learning and teaching (Colegrove, 2016; Glatthorn, 2019; Johnson, 2017; Subramanianet al, 2013).

Subramaniam et al (2013) examined the role of school librarians in enhancing science learning. While conducting the design-based research, they provided concrete examples of how librarians encouraged young people to learn science and facilitated social interaction in science. A school program called SciDentity was implemented in middle schools (grades 6 through 8). School librarians assisted the researchers to design sessions of science inquiry. They introduced information search process models and information literacy skills into the search process. They conducted inquiry based learning by guiding students in their search process and improving their information literacy skills. As a result, students were able to make authentic works through information searching, storytelling, and using technology. As an important motivational factor, librarians linking science with students' interest and learning by media and technology.

Although some studies that emphasize the role of the library in facilitating STEM education (see, for example, Subramaniam, Fleischmann \& Druin, 2012), there are also studies that emphasize its limitations (Lankes, 2015, Mardis, 2007). Lankes states that librarians are often unequipped to be STEM educators. He states that librarians can't be all things to all people and opposes the idea that libraries should have a role in STEM. Although Mardis (2017) encourages the librarian role in facilitating STEM in schools, she admits there are limitations because of the lack of connection between librarians and science education. Coding workshops are seen by some as a good way to expose young people to STEM related fields. Crystle (2017) found, through a series of Scratch workshops and related interviews, what supports are needed for librarians who want to offer coding workshops. Some of facilitatory factors are peer and mentor interest-driven learning, support of creativity, easy-to-use materials and hiring young interns to help facilitate.

Stohlmann et al. (2012) explored the main considerations for teaching integrated STEM education in schools. Through integrated STEM education, such as Project Lead The Way, students "investigate solutions to real world problems through designing, expressing, testing and revising their ideas" (Stohlmann, et al., 2012, p. 30). Other authors have pointed out the good influence of library-based STEM education on minorities and girls (Subramaniam, et al., 2018; Wang \& Degol, 2013; Wang \& Degol, 2017). Early STEM education in schools could lower the gender gap in the pursuit of careers in science, technology, engineering and mathematics. It could possibly help lower the socioeconomic and poverty gap.

Stohlmann et al. found that integrated STEM education requires numerous materials and resources that may include "construction tools such as saws, measuring devices and hammers; electronic materials such as computers, design programs, robotic kits, and calculators; and other material used in design, which could include wood, styrofoam, glue, cardboard or construction paper” (Stohlmann et al., 2012, p. 30). 
To implement STEM education, schools should provide support for teachers, through partnering with a university or nearby school, providing professional development, and assuring teacher collaboration time.

\section{Methodology and Research Design}

The research methodology used to examine Croatian primary schools curriculums was primary qualitative content analysis. Content analysis is a highly flexible research method widely used in library and information science (Domas White \& Marsh, 2006). Analytical constructs are used to move from the text to the answers to the research questions. The analytical construct is, in this case, an interrelationship between STEM education and activities planned by school librarians as professional associates in schools. Qualitative content analysis is flexible in the use of inductive and deductive analysis. Since the purpose of the study is to investigate a problem that is limited or fragmented on a local level, an inductive analysis is performed. Since there are numerous studies on this phenomenon on the global level, deductive analysis is also considered (Cho \& Lee, 2014).

The research goal was to analyse and illustrate STEM activities represented in school curriculums supported by school librarians. The research questions were: 1) How much are STEM activities carried out by librarians represented in elementary school curriculums? 2) Which and what kind of STEM activities are represented?

\section{Collecting the data}

Through content analysis of school curriculums, the specific area of activities planned by librarians was examined. This research intended to determine how many of Croatian school libraries plan STEM activities through simple quantitative analysis by noting frequencies and to describe how they planned to carry them out. Conclusions were drawn about librarian viewpoint on planning of their activities in school curriculum and the situation surrounding its creation, including the sociocultural background (Domas White, \& Marsh, 2006). The research included the school curriculums of 854 Croatian primary schools, which were available on their official web pages. There were 904 Croatian primary schools, at the time that the research was conducted, according to the official list provided by the Ministry of Science and Education in Croatia (Ministarstvo znanosti i obrazovanja Republike Hrvatske, 2019). The research findings are based only on data from the 2018/2019 school year and give a general picture of the STEM activities in school curriculum associated with the work of school librarians.

\section{Analysis and Results}

A simple analysis, noting frequencies of the STEM activities in school curriculums that were planned to be guided or assisted by school librarians, showed that most of the curriculums that were considered did not contain such activities ( 732 out of 854 curriculums, or $85.7 \%$ ). The data was obtained by simply recording the frequency of the occurrence of STEM activities in which the librarian had a role.

Content analysis showed that some STEM activities were present, but they were not always clearly defined and, in some cases, it was not possible to evaluate to what extent a librarian was involved and in what role. However, the fact that not many school curriculums contained STEM activities guided or supported by librarian does not necessarily mean that librarians didn't carry out some elements of STEM. The school library as a place can often be viewed logistically, as a place to carry out STEM activities as a part of school science teaching. It was not always clear if the library was being used only as a place or as a service. An aggravating factor was that the form of school curriculums is not specified and standardized. For these reasons, content analysis was chosen to be primary qualitative research method for this study and it also gives concrete examples of STEM activities planned by or with librarians.

International Association of School Librarianship

https://iasl-online.org 


\section{Findings and Discussion}

The goal of this paper is to give an overall picture of STEM activities in school curriculums that are supported by librarians. Findings fell into several categories: science, green libraries, technology, engineering, mathematics, and extracurricular activities. Some categories naturally overlap semantically, but the criteria for placement in the categories were mostly clear.

\section{Science}

Content analysis showed involvement of librarians in math lessons, geography, and biology lessons. Chemistry classes taught in cooperation with librarians in the framework of civic education were also identified, as well as the project "Geographers" and individual geography investigations in the school library. The goal of the geography project was expanding geographic knowledge beyond the prescribed curriculum. Science projects, such as "Meteorology of everyday life," "Hocus-pocus in library," "Balt...Balt...Baltazar!," "The universe unifies the world," "Human - it is me," "What can water do?" and "Little genius" are planned in school curriculums. There were also extracurricular activities "Young Explorer and "Little Scientists."

"Little scientists" do simplified experiments adapted to the age of future 1st grade students, such as, for example: which is faster to melt, which rolls faster? A school librarian was the conceptual initiator and project coordinator of "Project Balt...Balt...Baltazar!" The purpose of this project was to introduce students to the Croatian animated film, to familiarize students with the stop motion recording technique, to inspire interest in physics and chemistry by conducting experiments, and to develop ecological awareness. The plan includes art and literary workshops, lectures, experiments, film projections, and performances.

Activities in the program "The universe unifies the world"--celebrating World Space Week (WSW)--were planned to learn the basics of astronomy by searching data sources; to create artistic and literary expression related to the topic; and to search books, encyclopedias and digital sources. Science workshops in correlation with the physics teacher were planned, including (if possible) a visit to the Planetarium or the Observatory of Zagreb. The goal of the project "Human - it is me" is to encourage the preservation and strengthening of the body and to develop responsible behaviours towards one's own health. Program activities includes visiting a school library and finding interesting information about the human body according to the student's interest.

Celebration of World Inventor Day is included in one curriculum and Fighting AIDS World Day in another. One curriculum reports school participation in UNESCO ASPNet network of associated schools with goals of creating, teaching, learning and interacting. On their official web pages, creative involvement in STEM is visible (UNESCO Associated School Network, n.d.).

One interesting project which involved the public library (but did not include school librarian) was called "Scientific classroom." Organized by the public library for the 3rd graders, its goal was the advancement and promotion of mathematics as science, introduction of abacus in the daily teaching of mathematics, encouraging students to develop and apply mathematical thinking in problem solving, different activities and everyday situations. It is not clear why the school librarian was not involved in project planning.

One curriculum reports training of students for independent research work, evaluation of web information, and using computers for making school presentations, reports and posters. Many librarians do that and similar activities but they do not plan it within the school curriculum. Some curriculums

International Association of School Librarianship

https://iasl-online.org 
reported encouraging use of library resources in educational activities. One librarian planned to conduct project called Guided inquiry in cooperation with teachers of different subjects, maybe including STEM areas. Visiting museums, observatories, geological and speleological facilities, and the Center of Technical Culture Rijeka were planned by librarians as well.

\section{Green Libraries}

Numerous ecological activities of school librarians were noted in school curriculums, for instance: "Project Green school," "White stork and eco-corner," "A school garden with spices, aromatic and medicinal herbs," "'Ecological action - school landscaping," "Ecology - the way of life," "testing of living conditions in waters" (out-of-classroom learning), International eco-schools (school librarian is a member of the research team), "Little guardians of nature" (in cooperation with school library), "The Youngest for Croatian Waters," and "Protected areas of nature in our county" (of-classroom teaching).

These projects, workshops and extracurricular activities are based on ecology, zoology and botany that aim to develop the consciousness about environment protection. Some of these activities originated from national project "Green libraries," which was initiated by the Society of Librarians of Istria started in March 2011. The goal of the project is to educate the public and to spread awareness of sustainable societies and the necessity of environmental protection through the Green Library portal, documentary film projections, professional lectures, forums and book promotions (Zelena knjižnica, 2012). The author and project manager is Ivan Kraljević from the University Library in Pula. The general goal was to involve the public in environmental protection. Project beneficiaries are primarily pupils and students, as well as the general public (Kraljević, 2013, pp. 200-201). The term "green library" refers in this case to library programs and services with the goal to develop green literacy, inform and develop consciousness about sustainable society and environmental protection (Dragaš, 2017, p. 223.). This kind of Croatian practice follows the principles and guidelines expressed in IFLA's and UNESCO's official documents (Dragaš, 2017).

Many schools in Croatia have a particular eco-status awarded by the Association "Udruga Lijepa naša" as the national coordinator of the international project of Eco schools. International Eco schools is a program designed to implement environmental education guidelines at the level of educational institutions (primary and secondary schools, kindergartens and dormitories, schools for children with special needs and faculties). Program steers the regular educational curriculum in the way of waste reduction and disposal, rational use of energy and water, and the maintenance and preservation of the school environment (Udruga Lijepa naša, n.d.). In the analysed school curriculums librarians were mostly involved in the eco-school project program as members of research teams or as members of eco committees.

Librarians often organize activities to mark Earth Day and World Water Day celebrations. Art elements are added to STEM, making it STEAM, through painting eco-friendly shopping bags, creative recycling workshops, and literary workshops. The contest organized by the "Croatian waters" for elementary school students invites students to choose from categories such as: educational material; research project / workshop; art works; slogans / tracks and a message or a short spot (Hrvatske vode, 2019.) The competition is not intended primarily for librarians, but they can certainly find their place in it.

Out-of-classroom teaching often promotes ecology issues, as students visit national parks, nature parks, and other protected areas in the country. Through extracurricular activities like "Ecologist" and "Little

International Association of School Librarianship

https://iasl-online.org 
guardians of nature," students can learn and investigate more about ecology with a librarian's guidance or library fund support. Librarians mainly participate in such activities as a teacher's coordinator.

\section{Technology}

School librarians are often intermediaries between information and communication technology and students. Through their educational work, they teach usage of online reference collections, online catalogues and databases. They promote safer and more responsible use of online technologies and mobile devices through projects like "Safety on the Internet" and "Safer Internet Week." They also help students develop communication skills and digital competences. Projects encourage learners to actively learn by playing, investigating and creating and to encourage long distance learning and cooperation in digital environment. E-twinning projects encourage use of information and communication technology.

Librarians are often multimedia support and demonstrators of the different possibilities of using the IT classroom and the modern technology. Numerous student training programs referring to the need for information and communication technology in everyday learning and work are noted. As stated in one curriculum, they are intended to provide children and teachers with opportunities to: apply ICT for educational, work and private needs; responsibly, morally and securely use ICT; communicate effectively and collaborate in a digital environment; to inform and critically evaluate and select technology and to use technology for appropriate purposes; to manage information; to create and edit new ones; to make students e-portfolios, etc. There are school website management activities as well as web journalism with students as reporters. In "Project Info2.0mania," librarians teach students how to use web 2.0 tools for learning and entertainment. "Project Let's make e-creatively, "organized by the Croatian Association of School Librarians, encourages the creation of student work in web 2.0 tools in the school library (Hrvatska udruga školskih knjižničara [HUŠK], n.d.).

One Green library project was planned through inter-subject theme: Using of information and communication technology. Project TIC TAC workshops (Tactile Innovative Creative - Technological Applicable Collaborative) was noted in one school curriculum. The purpose of the project was to encourage communication among pupils from different countries, to adopt computing skills, to make a product using a computer program, to make a picture book or a comic about web tools, to connect ICT with art and to develop attitudes, knowledge and skills of a multidisciplinary approach to connect mathematics, informatics, technical drawing, visual culture, nature and society and Croatian language.

\section{Engineering}

Visiting educational exhibition of Lego dice was planned in one of the curriculums. "Project Pro Mikro" was planned by one librarian to introduce algorithmic thinking and problem solving approach to different subjects and extracurricular activities by the use of microcomputers. Another one has planned to participate in the The Croatian Makers League. It is a part of the Croatian Makers project launched in 2014 by the Institute for Youth Development and Innovation. The goal is to include robotics, automatics and programming in elementary school education (Institut za razvoj i inovativnost mladih [IRIM], 2019).

\section{Mathematics}

There were many mentions of librarians involved in mathematics activities, such as organizing a Math evening, an online computing competition (the Beaver Computing Challenge), and the international math competition, "Kangaroo without Borders (Kangaroo of Mathematics). 
Math Evening is a set of interactive workshops that encourage students to develop a positive attitude toward mathematics. The main sponsor of the Evening of Mathematics was Institute for Youth Development and Innovation (Hrvatsko matematičko društvo, 2019). During the Math evening, students solve mathematical tasks, while teachers organize games and prepare accessories and provide support for students. The fun side of mathematics is being revealed that way (Hrvatsko matematičko društvo, 2019).

Beaver Computing Challenge promotes computer science and computer thinking among teachers and students. Online competition consists of a series of challenging tasks designed by experts from around fifty countries. The competition for Croatia is organized by the Associates in Learning with the support of the Croatian Association of Informatics, Algebra College and CARNET, sponsored by the Ministry of Science and Education (Suradnici u učenju, 2019).

Math kangaroo is an international mathematical competition established in 1991 by André Deledicq, a professor of mathematics at the University of Paris 7, and Jean-Pierre Boudine, professor of mathematics at Marseille. In Math kangaroo, mathematical thinking is tested, rather than formal math knowledge (Math kangaroo, n.d.). Motto of the competition is: no selection, elimination and finals. The competition is funded by the membership fee (Hrvatsko matematičko društvo, 2019).

In one curriculum, a Mathematical March festival was to be held, one of its components being an exhibition in the school library. Another curriculum contains a plan for math quizzes, games and competitions where school librarian is listed as a needed human resource, and in another the librarian is listed as a cooperator in mathematical-logical-scientific-technological area for students from 1st to 3rd grade. The goals of an "Erasmus + project, The colors of knowledge" were to raise the environmental awareness and responsibility of students, to popularize mathematics and natural sciences and to introduce students to new learning methods and technologies. According to the description, the project combines several areas of STEM, which represents integrated STEM.

\section{Extracurricular activities}

One of the most common extracurricular activities in primary schools in Croatia is "Little librarians." However, in only one case was it reported that "Little librarians" was used for introducing science into the library - STEM for students from first to fourth grade to gain practical knowledge. STEM in the library was planned to be carried out in cooperation with teachers, in accordance with the curriculum. Concrete activities listed included: information education (solving an information problem, library databases searching, abstract shaping, evaluation of information on web pages, ICT use), visiting Technical Museum Nikola Tesla, extra work with gifted students with the goal of enrichment of teaching content in Geography called Project Lumen, and an exhibition at the school library with a theme "The Earth from the universe." There was also an extracurricular activity for the group of gifted students which included listening and presenting exercises, solving logical puzzles, creative problem solving exercises, and three-dimensional and two-dimensional creating. One school reported in its curriculum establishing an E-library by a Reading club which is carried out by a school librarian. Education on how to use e-books on tablets is provided in the club. Reading clubs can develop digital competencies, among other skills. Other extracurricular activities supported by a school librarian included a Young chess players group and a Young geographers group.

\section{Implications and Conclusions}

The curriculum analysis of elementary schools in Croatia for the school year 2018/2019 showed that most librarians did not plan to perform STEM activities for this school year. The reason for this may be the fact

International Association of School Librarianship

https://iasl-online.org 
that Croatian educational system is yet to turn its focus on the STEM area. In the Great Educational Reform which is to start with the school year 2019/2020, the importance of STEM area has been greatly emphasized, which was not the case before. Having that in mind, to some extent it is understandable that most librarians did not devote their time and energy to topics and activities related to the STEM. Yet, there are some librarians who chose to incorporate STEM into their work, as the results of this research have shown. Further national research is needed to clarify the results of this curriculum analysis of Croatian primary schools. These studies should include a number of factors and their impact on STEM activities: space, equipment, fund structure, socioeconomic indicators, and cooperation with science teachers. It would also be advisable to conduct an analysis of annual reports of librarians on their work in order to determine how many of the planned activities are actually realized. School librarians should be facilitated at a structural and infrastructural level to carry out the desired activities. Unfortunately, many libraries do not have the space and equipment suitable to meet the official standard for school libraries, so they cannot serve as logistical centres for others and therefore have to re-locate their services from the library to classrooms or outdoors. In that process, a librarian needs to consider many things: collaboration with (other) teachers, collision with other school activities, and funding which are all aggravating factors. It would be advisable for future studies to examine correlation between library space, equipment and collections and some areas of library performances and impact, such as STEM.

If we want to encourage librarians to implement and support STEM activities, it is necessary to establish activities and projects for the school librarians of higher educational and library institutions. Librarians should be encouraged to get involved in such activities and find their place in this stratified coverage area called STEM. Many authors have given recommendations and examples of good practice concerning STEM. But in order to apply them, librarians need systematic removal of barriers. It is important to mention that there is no prescribed curriculum for school librarians in Croatia, so they shape their activities mainly according to wishes and possibilities. Keeping this in mind, the question that brings us back to the beginning is: Should school librarians get involved in STEM activities? They certainly do not have to, but as professional associates, maybe they should establish cooperation in these areas where traditionally they are not expected to. And maybe they should not try to be everything to all people, as Lankes (2015) states. Good task management is essential for all collaborative activities, including STEM. To finally conclude: "Innovations in education are of particular importance because education plays a crucial role in creating a sustainable future" (Serdyukov, 2017). The implementation of STEM into school curriculum can certainly be considered as innovation.

\section{REFERENCES}

Cho, J. Y. \& Lee, E. (2014). Reducing Confusion about Grounded Theory and Qualitative Content Analysis: Similarities and Differences. The Qualitative Report, 19(32), 1-20. Retrieved from http://nsuworks.nova.edu/tar/vol19/iss32/2

Colegrove, P .T. (2016). Makerspaces in libraries: technology as catalyst for better learning, better teaching. Ingeniería Solidaría13(21), 19-26. doi: http://dx.doi.org/10.16925/in.v13i21.1724

Crystle, M. (2017). Libraries as Facilitators of Coding for All. Knowledge Quest, 45(3), 46-53. Retrieved from: https://files.eric.ed.gov/fulltext/EJ1125376.pdf

Domas White, M. \& Marsh, Emily E. (2006). Content Analysis: A Flexible Methodology. Library trends, 55(1), 22-45. Retrieved from http://hdl.handle.net/2142/3670

International Association of School Librarianship

https://iasl-online.org 
Dragaš, B. (2017). Zelene knjižnice za zelenu pismenost: hrvatsko iskustvo. Vjesnik bibliotekara Hrvatske, 60(4), 221-241.

Glatthorn, A., Boschee, F., Whitehead, B. M., \& Boschee, B. F. (2019) Curriculum Leadership: Strategies for Development and Implementation. Los Angeles, CA: SAGE Publications.

Hrvatske vode. (n.d.) Retrived from: https://www.voda.hr/hr/search/node/najmla\%C4\%91i

Hrvatsko matematičko društvo. (2019). Retrived from: http://www.matematika.hr/

Institut za razvoj i inovativnost mladih. (2019). Croatian Makers liga. Retrived from https://croatianmakers.hr/hr/croatian-makers-liga/

Johnston, M. P. (2017). Preparing Teacher Librarians to Support STEM Education. In L. Farmer (Ed.). Learning Without Borders. International Association of School Librarianship Conference Proceedings (pp. 1-12). Long Beach, California, USA.

Kraljević, I. (2013). Zelena knjižnica: projekt društva bibliotekara Istre. Vjesnik bibliotekara Hrvatske, 56(3), 199-204.

Lankes, R. D. (2015). Expect More: Why Libraries Cannot Become STEM Educators. Paper presented at the Public Libraries \& STEM: A National Conference on Current Trends and Future Directions, Denver, Colorado, 20-22 August (pp. 1-6).

Mardis, M. (2007). School Libraries and Science Achievement: A View from Michigan's Middle Schools. School Library Media Research: Research Journal of the American Association of School Librarians, 10, 1-29. Retrieved from http://www.ala.org/aasl/sites/ala.org.aas1/files/content/aaslpubsandjournals/slr/vol10/SLMR_Scho olLibScienceAchievement V10.pdf

Math kangaroo. (n.d.) About. Retrieved from https://www.mathkangaroo.in/about/introduction

Ministarstvo znanosti i obrazovanja Republike Hrvatske: Osnovne škole. (2019, March 14) Retrieved from http://mzos.hr/dbApp/pregled.aspx?appName=OS\#

Nacionalni okvirni kurikulum za predškolski odgoj i obrazovanje te opće obvezno i srednjoškolsko obrazovanje (2011). Zagreb: Ministarstvo znanosti, obrazovanja i športa. Retrieved from: http://mzos.hr/datoteke/Nacionalni okvirni_kurikulum.pdf

Niemi, H. , Harju, V., Vivitsou, M. , Viitanen, K. , Multisilta, J., \& Kuokkanen, A. (2014) Digital Storytelling for 21st-Century Skills in Virtual Learning Environments. Creative Education, 5, 657-671. doi: 10.4236/ce.2014.59078

Nadelson, L. S., Callahan, J., Pyke, P., Hay, A., Dance, M., \& Pfiester, J. (2013). Teacher STEM Perception and Preparation: Inquiry-Based STEM Professional Development for Elementary Teachers, The Journal of Educational Research, 106(2), 157-168, doi: 10.1080/00220671.2012.667014

Sanders, M. (2008). STEM, STEM Education, STEMmania. The Technology Teacher, 68(4), 20-26. Retrieved from https://vtechworks.lib.vt.edu/handle/10919/51616 
Serdyukov, P. (2017). Innovation in education: what works, what doesn't, and what to do about it?. Journal of Research in Innovative Teaching \& Learning, 10(1), 4-33. Retrieved from https://doi.org/10.1108/JRIT-10-2016-0007

Stohlmann, M., Moore, T. J. \& Roehrig, G. H. (2012). Considerations for Teaching Integrated STEM Education. Journal of Pre-College Engineering Education Research (J-PEER), 2(1). Retrieved from https://docs.lib.purdue.edu/jpeer/vol2/iss1/4/

Hrvatska udruga školskih knjižničara. (n.d.) Stvarajmo eKreativno. Retrieved from https://stvarajmoekreativno.weebly.com/

Subramaniam, M., Ahn, J., Fleischmann, K. R., \& Druin, A (2012). Reimagining the Role of School Libraries in STEM Education: Creating Hybrid Spaces for Exploration. The Library Quarterly: Information, Community, Policy, 82(2), 161-182. Retrieved from: https://doi.org/10.1086/664578

Subramaniam et al. (2013). The role of school librarians in enhancing science learning. Journal of Librarianship and Information Science, O(0)1-14. doi: 10.1177/0961000613493920

Subramaniam, M., Scaff, L, Kawas, S., Hoffman, K. \& Davis, K (2018). Using Technology to Support Equity and Inclusion in Youth Library Programming: Current Practices and Future Opportunities. Library Quarterly: Information, Community, Policy 88(4), 315-331. Retrieved from https://www.journals.uchicago.edu/doi/pdfplus/10.1086/699267

Suradnici u učenju. (2019). Dabar. Retrieved from http://ucitelji.hr/dabar/

Udruga Lijepa Naša Zagreb. (n.d.) Eko škole. Retrieved from: https://www.lijepa-nasa.hr/eko-skole/

UNESCO Associated School Network. (n.d.). About the network. Retrieved from https://aspnet.unesco.org/en-us/Pages/About the network.aspx

Wang, M. T., \& Degol, J. (2013). Motivational Pathways to STEM Career Choices: Using Expectancy-Value Perspective to Understand Individual and Gender Differences in STEM Fields. Developmental review, 33(4), 1-49. doi: 10.1016/j.dr.2013.08.001

Wang, M. T., \& Degol, J. L. (2016). Gender Gap in Science, Technology, Engineering, and Mathematics (STEM): Current Knowledge, Implications for Practice, Policy, and Future Directions. Educational psychology review, 29(1), 119-140. doi:10.1007/s10648-015-9355-x

Zelena knjižnica. (2012). O projektu. Retrived from http://zk.dbi.hr/o-projetku/

\section{Biography}

Ana Rendulić graduated from the Faculty of Philosophy Osijek, Department for Information and Communication Sciences in 2013. Since then she has worked in several school libraries. She is currently employed at two primary school libraries. She is also a $\mathrm{PhD}$ student in Information and communication sciences at the University of Zagreb. 